\title{
Comparative Study of Curcuma Longa and Beta Extracted Dye Applied on Dye Sensitized Solar Cells
}

\author{
Ayoub, J. P.; Tractz, G. T.; Dias, B. V.; Banczek, E. P.; Rodrigues, P. R. P.*
}

Rev. Virtual Quim., 2019, 11 (6), 1908-1919. Data de publicação na Web: 2 de janeiro de 2020

http://rvq.sbq.org.br

\section{Estudo Comparativo Corante Extraído de Curcuma Longa e Beta Aplicado em Células Solares Sensibilizadas por Corantes}

Resumo: As células solares sensibilizadas por corante (DSSC) mostraram vantagens, como um método alternativo para reduzir a emissão de gases poluentes e baixos custos de produção. Alguns corantes naturais podem ser aplicados em DSSC, uma vez que possuem moléculas fotossensíveis, como flavonóides e terpenos, presentes na composição cromofórica e nos grupos auxocromos. Esses grupos podem absorver energia do sol gerando células com diferentes parâmetros, devido à estrutura química da molécula. $O$ objetivo deste trabalho é produzir e caracterizar células solares de $\mathrm{TiO}_{2}$, com corantes naturais extraídos de Curcuma Longa e Beta, verificando quais apresentam melhores parâmetros fotoquímicos. As técnicas de caracterização empregadas foram: Espectroscopia UV - VIS, Potencial Circuito Aberto em função do tempo (Voc), Fotocronoamperometria $(j-t)$, Curvas de densidade de corrente em função do potencial (j - V) e Espectroscopia de Impedância Eletroquímica (EIS). Os resultados indicaram que a célula produzida com Curcuma Longa é menos resistente ao fluxo de corrente e com maior revestimento sob a superfície do $\mathrm{TiO}_{2}$, com parâmetros fotovoltaicos de $\mathrm{j}=0,860$ $\mathrm{mA} \mathrm{cm} \mathrm{cm}^{-2}$ Voc $=0,535 \mathrm{~V} ; \mathrm{FF}=0,560$ e $\eta=0,260 \%$.

Palavras-chave: Antocianina; célula de Gratzel; energia renovável; corante natural.

\begin{abstract}
Dye sensitized solar cells (DSSC) has shown advantages, as an alternative method to reduce the emission of polluting gases, and low production costs. Some natural dyes can be applied in DSSC, since they have photosensitive molecules, as flavonoids and terpenes that present in the composition chromophoric and auxochrome groups. These groups might absorb energy from the sun generating cells with different parameters, due to the chemical structure of the molecule. The aim of this paper is produce and characterize solar cells of $\mathrm{TiO}_{2}$, with natural dyes extracted from Curcuma Longa and Beta, verifying which present better photochemical parameters. The characterization techniques employed were: UV - VIS Spectroscopy, Open Circuit Potential as a function of time ( $\mathrm{Voc})$, Photocronoamperometry (j-t), Current density curves as a function of potential $(\mathrm{j}-\mathrm{V})$ and Electrochemical Impedance Spectroscopy (EIS). The results indicated that the cell produced with Curcuma Longa is less resistive to current flow and with higher coating under the surface of $\mathrm{TiO}_{2}$, with photovoltaic parameters of $\mathrm{j}=0.860 \mathrm{~mA} \mathrm{~cm}^{-2}$; $\mathrm{Voc}=0.535 \mathrm{~V} ; \mathrm{FF}=0.560$ and $\eta=0.260 \%$.
\end{abstract}

Keywords: Anthocyanin; Gratzel cell; renewable energy; natural dyes

\footnotetext{
* Universidade Estadual do Centro Oeste, Programa de pós-graduação em Bioenergia, Rua Simeão Camargo Varela de Sá 3, CEP 85040-080, Guarapuava-PR, Brasil.

$M$ prprodrigues@gmail.com DOI: $\underline{10.21577 / 1984-6835.20190133}$
} 


\title{
Comparative Study of Curcuma Longa and Beta Extracted Dye Applied on Dye Sensitized Solar Cells \\ Julianno Pizzano Ayoub, Gideã Taques Tractz, Bianca Vanjura Dias, Everson do Prado Banczek, Paulo Rogério Pinto Rodrigues*
}

Universidade Estadual do Centro Oeste, Departamento de Química, Laboratório do Grupo de Pesquisa em Eletroquímica - GPEL ${ }^{\circledR}$, Rua Simeão Camargo Varela de Sá 3, CEP 85040-080, Guarapuava-PR, Brasil.

\author{
prprodrigues@gmail.com
}

Recebido em 20 de agosto de 2019. Aceito para publicação em 8 de novembro de 2019

\section{Introduction \\ 2. Materials and Methods \\ 3. Results and Discussion \\ 4. Conclusions}

\section{Introduction}

The great expansion of the use of nonrenewable energy resources to supply world energy demand has brought new means of energy conversion. ${ }^{1}$ Among the various technologies, there is solar energy. ${ }^{1,2}$

Solar cells are devices that can convert solar energy into electricity from the photovoltaic effect. ${ }^{3}$ Thirth generation of PV devices, as Organic Solar Cells (OSC), Perosvkite Solar Cell (PVKSC), Quantum Dots Sensitized Solar Cells (QDSSC) and Dye Sensitized Solar Cells (DSSC) have some advantages, as easy production, low cost and low toxicity. Dye-sensitized systems (DSSC) have been developed by Gratzel in 1991, and have been studied by researches of the whole world, due good efficiency. ${ }^{3,4,5}$
The operation of the DSSC (Fig -1) is based in sunlight absorption by the photo sensitizer, which gets excited and injects electrons from the photoexcited state into the conduction band of semiconductor. ${ }^{6}$ To complete the circuit, the dye must be regenerated by electron transfer from a redox species in a solution which is the reduced at the counter electrode. $^{7}$

In last years, several metal compounds have been synthetized and used as sensitizers, featured Ru based complexes, as N719 (Ditetrabutylammonium cis-bis (isothiocyanato) bis (2,2'-bipyridyl-4,4'-dicarboxylate) ruthenium (II) (Figure 1B), because they have a large absorption on visible, and infrared region of spectrum. However, they have a higher cost of production, and the natural dyes become a viable alternative, as demonstrated by Hagfeldt et al. ${ }^{8,9,10}$ 


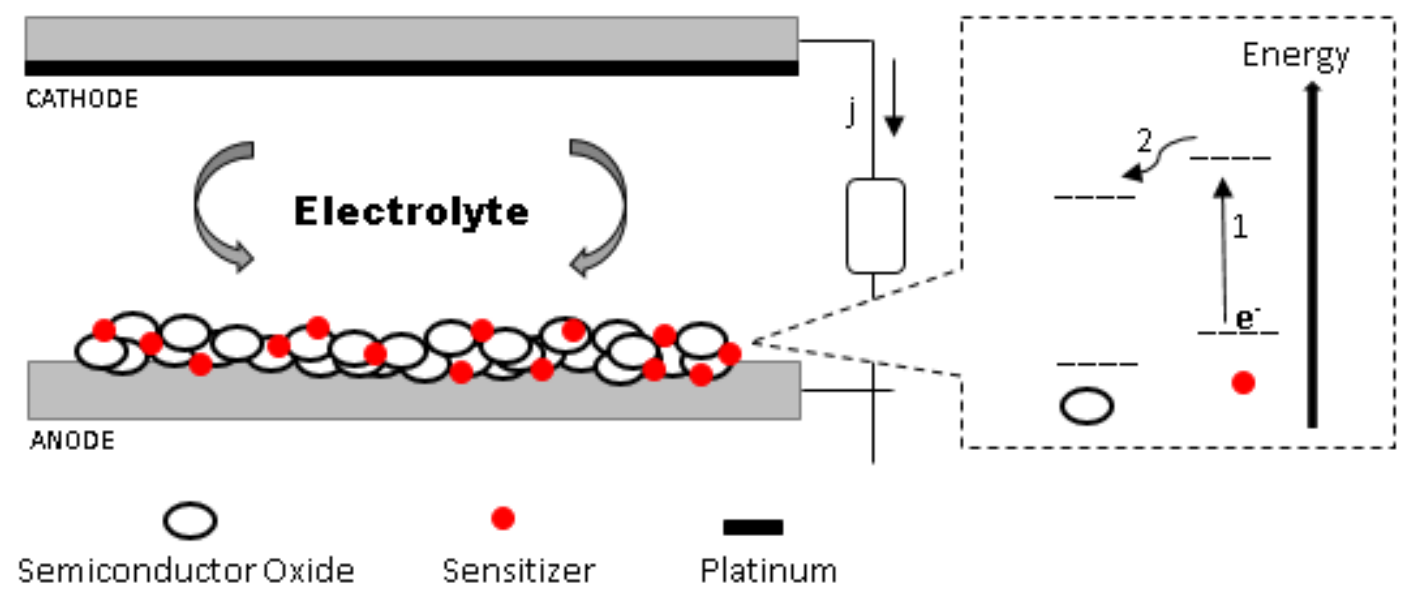

Figure 1. Schematic overview of DSSC. Reaction 1 represents the electronic photoexcitation of the dye and reaction 2 electron injection in the semiconductor oxide

The use of natural dyes is possible due the presence of metabolites such as flavonoids and terpenes in natural products and they can be extracted by ethanoic solution. These molecules have chromophore groups in their structures and double conjugated bonds leading it to present photosensitivity

A<smiles>COC(Cc1c(O)cc(O)cc1O)C(=O)c1cc(O)c(O)c(O)c1</smiles>

character, which allows their use in DSSCs. ${ }^{11,12,13}$ Anthocyanins (Fig - 2A) that are colored water-soluble pigments belong to the class of flavonoids, and the curcumin (Fig- 2C) are part of the terpene class. The chemical structures anthocyanin and curcumin are shown in Figure $2 .{ }^{14,15}$

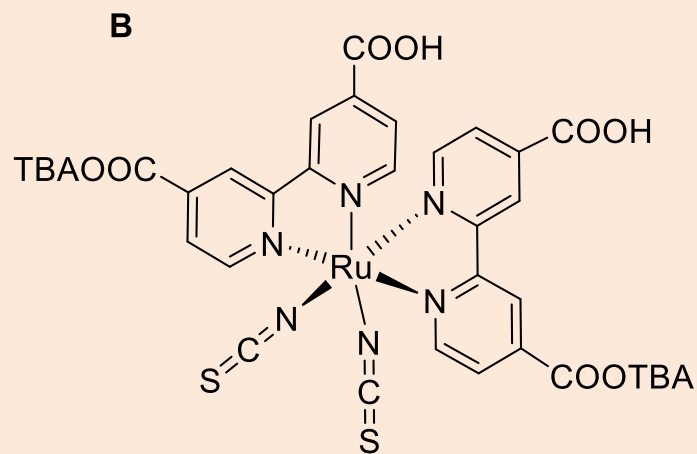<smiles>COc1cc(/C=C/C(=O)/C=C(O)/C=C/c2ccc(O)c(OC)c2)ccc1O</smiles>

Figure 2. Chemical structure of the anthocyanin molecule in A, N719 in B and curcumin in C

As shown in Figure 2, both metabolites have very distinct structures, one of them is rich in $\mathrm{OH}$ groups and the other one has a large number of conjugated bonds and $\mathrm{OCH} 3$ groups, which, as demonstrated by Kumara et al, may be a factor of extreme importance for the good photochemical response of these molecules. ${ }^{9}$ In this context, this paper aims to produce and characterize solar cells with dyes extract from natural products as betas rich in anthocyanin and Curcuma Longa that contain curcumin molecules. 


\section{Materials and Methods}

The $\mathrm{TiO}_{2}$ aqueous paste was prepared as demonstrated by the flowchart in Figure $3{ }^{16,17}$ The paste was deposited on fluorine-doped tin oxide (FTO $\sim 7 \Omega$ sq-1) by employing doctor blading method, followed by calcination for 30 minutes at $450{ }^{\circ} \mathrm{C}$, as described in Figure $3 .{ }^{18}$
The dye was extracted from saffrom (Curcuma Longa var.) and beet (Beta var.) in ethanol solution with citric acid $(3 \% \mathrm{~m} / \mathrm{m})(\mathrm{pH}$ $=4.5$ ) After 12 hours of extraction at $5^{\circ} \mathrm{C}$, the films were immersed in the dye solution for impregnation for 24 hours to ensure a well adsorption of the molecules on the semiconductor oxide surface. ${ }^{19}$

\section{$3 \mathrm{giO}_{2} / 0.1 \mathrm{~mL}$ PEG \\ 200/0.1 mL \\ acetylacetone $/ 1 \mathrm{~mL} \mathrm{H}_{2} \mathrm{O}$}
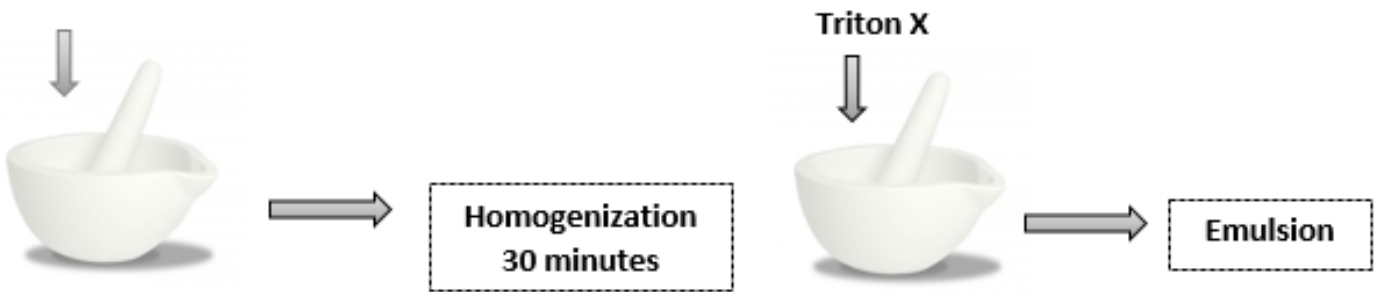

Figure 3. Scheme for $\mathrm{TiO}_{2}$ emulsion preparation

For counter electrode preparation, electrodeposited platinum under FTO, via cyclic voltammetry, was used with a three electrode-cell. The electrolytic solution was produced with $\mathrm{K}_{2} \mathrm{PtCl}_{6} 1.10^{-4} \mathrm{~mol} \mathrm{~L}^{-1}$ dissolved in $0.1 \mathrm{~mol} \mathrm{~L}^{-1} \mathrm{HCl}$. Four cycles were performed with a scanning speed of $10 \mathrm{mV} \mathrm{s}-1 \mathrm{vs}$ (Ag / $\mathrm{AgCl}) \mathrm{V} \pm 0.5 \mathrm{~V}^{20}{ }^{20}$ The cell was assembled in sandwich format of photoanode and cathode, with active area of $0.2 \mathrm{~cm}^{2}$ and with intermediate charge containing I- / 13- as redox couple.

The dye absorbance measurements were performed on a Gehaka 320G UV-VIS spectrophotometer, with a double beam at $25^{\circ} \mathrm{C}$, in order to determine the wavelength absorption. The dye absorption spectra onto $\mathrm{TiO}_{2}$ surface were obtained in an Ocean Optics (USB-2000) spectrophotometer coupled to a tungsten lamp with optics fiber in a range of $400 \mathrm{~nm}$ to $900 \mathrm{~nm}$.

The electrochemical measurements were performed using a Zhenium Zahner ${ }^{\circledR}$ potentiostat, with a Lot Oriel LS0106 solar simulation system controlled by a Xpot auxiliary potentiostat, with solar intensity of $100 \mathrm{~mW} \mathrm{~cm}^{-2}$, under simulated AM 1.5 solar illumination. j-V curves was performed to determinate the efficiency of harvesting light as demonstrated by Gratzel ${ }^{3}$

Photochronoamperometry measurements were performed by 660 seconds. The light was turn on and off at $60 \mathrm{~s}$ intervals. For the electrochemical impedance spectroscopy, a frequency of $0.01 \mathrm{~Hz}$ to $1 \mathrm{KHz}$ was used with amplitude of $10 \mathrm{mV}$.

\section{Results and Discussion}

Figure 4 shows UV-VIS spectra for the dyes extracted from Beta and Curcuma Longa.

It is depicted in Figure 4 the extracted dye from the beta, which showed a wider absorption in the electromagnetic spectrum ( $600 \mathrm{~nm}$ ) when compared to the Curcuma Longa dye ( $500 \mathrm{~nm}$ ). Synthetic dyes, ruthenium derivatives, exhibit the ability of absorbing at rather high wavelengths, even infrared regions ( $1100 \mathrm{~nm}$ ), as is the case with $\mathrm{N} 719$ dye, because it have $\mathrm{SCN}, \mathrm{COOH}$, and other auxochromes groups that can 
expend the absorption region, but this behavior is not observed for dyes extracted from natural products. ${ }^{8}$

According to Lopes anthocyanins present a $540 \mathrm{~nm}$ absorption peak, easily observable in beta dye, characteristic of the presence of the pyran group in the molecule, as shown in Figure $2,{ }^{21}$ indicating a success anthocyanin extraction. For the Curcuma Longa extracted dye, the yellow coloration itself is an indication of the high presence of terpenes and it is confirmed by its spectrum, since this last class of metabolites absorbs in regions of $430 \mathrm{~nm}$, not reaching the length of $500 \mathrm{~nm} .^{22}$ Others extraction methods, to verify the possibility to displace the absorption band for higher values was not analize in this paper.

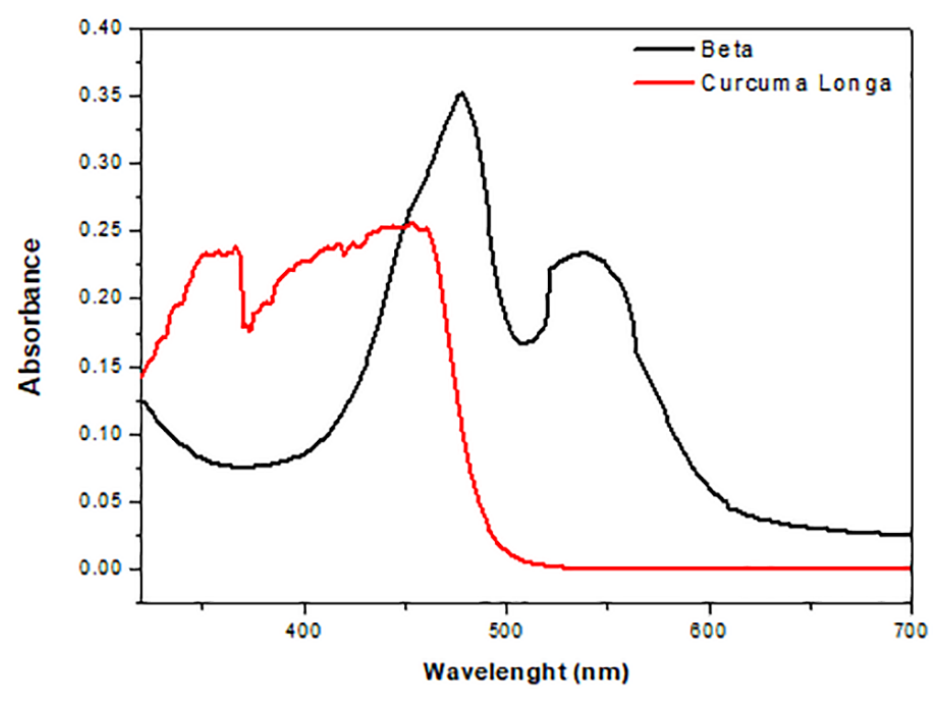

Figure 4. UV-VIS spectra of the dyes used extracted in ethanoic acidified solution at $\mathrm{pH}=4.5$ and concentration at $0,1 \mathrm{mg} \mathrm{L}^{-1}$

The fact that dyes derived from natural products have a small absorption in the electromagnetic spectrum, limits the energy conversion of these devices, but their production and availability becomes feasible due to the reduced cost. ${ }^{23}$ To verify the dye adsorbed on the surface of the semiconductor oxide, the UV VIS measurements of the films were performed and the results are shown in Figure 5.

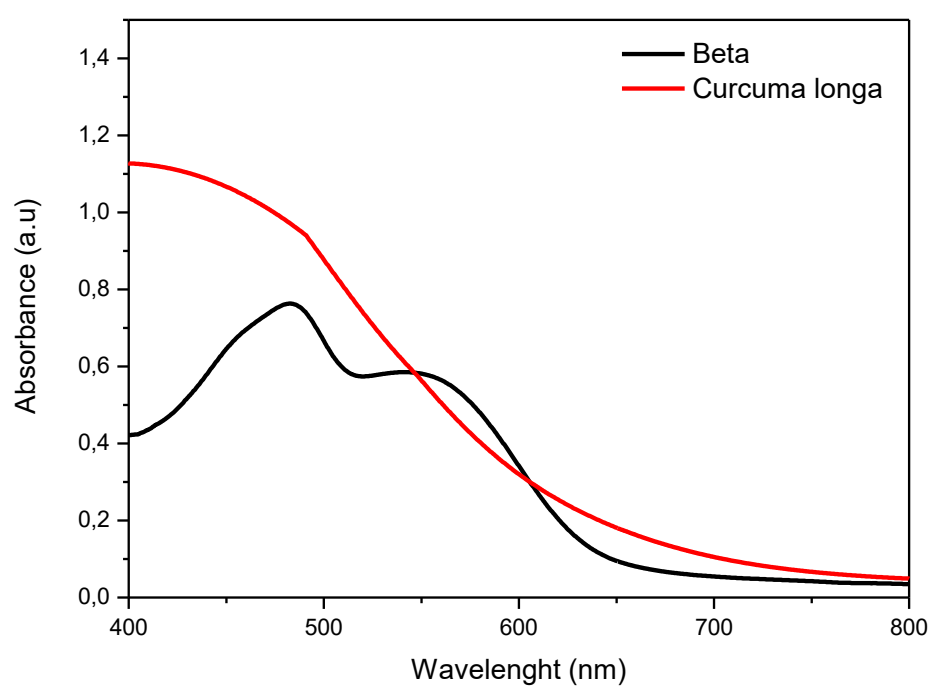

Figure 5. UV VIS absorption spectra for Beta and Curcuma Longa dyes on mesoporous $\mathrm{TiO}_{2}$ films 
During the sensitization of the film, it is expected that the hydroxyl groups will coordinate on the $\mathrm{TiO}_{2}$ surface, but the spectrum may be different when compared to the solutions, since not all of the substances can anchor themselves in the oxide. $\mathrm{Bare} \mathrm{TiO}_{2}$ present an absorption until $400 \mathrm{~nm}$, as demonstrated by Hagfeldt and co workers. ${ }^{8}$ The use of a dye allows better adsorption of light, consequently improving the photoconversion energy efficiency of the solar cell.

In Figure 5, it is possible to observe that both dyes have a wide absorption in the visible region $(400-600 \mathrm{~nm})$, it suggests the presence of molecules from natural products where they are absorbed. ${ }^{14}$ Chromophores and auxochromes groups present the characteristic to absorbe light, due containing natural groups as $-\mathrm{COOH},-\mathrm{OH}$ and others. ${ }^{8}$ It is also noticed that the film sensitized with
Curcuma Longa presents a higher absorption when compared to the dye from the Beta, indicating cells with better photoelectrochemical parameters, suggesting due better extraction of actives species, which will be verified in previous techniques.

For the verification of the maximum potential capacity generated by the cells, the following technique was use. The open circuit potential as a function of time, gives the potential value (V) that the cell generate ${ }^{17} \mathrm{In}$ the open circuit potential the current of the device is zero, so it is assume, that all ejected electron recombines with the electrolyte. This condition is extremely useful in analyzing the effects of recombination of charges inside the device, and limits the conversion to electricity, generating heat losses..$^{24,25}$ Figure 6 shows the obtained Voc measurements for the systems studied.

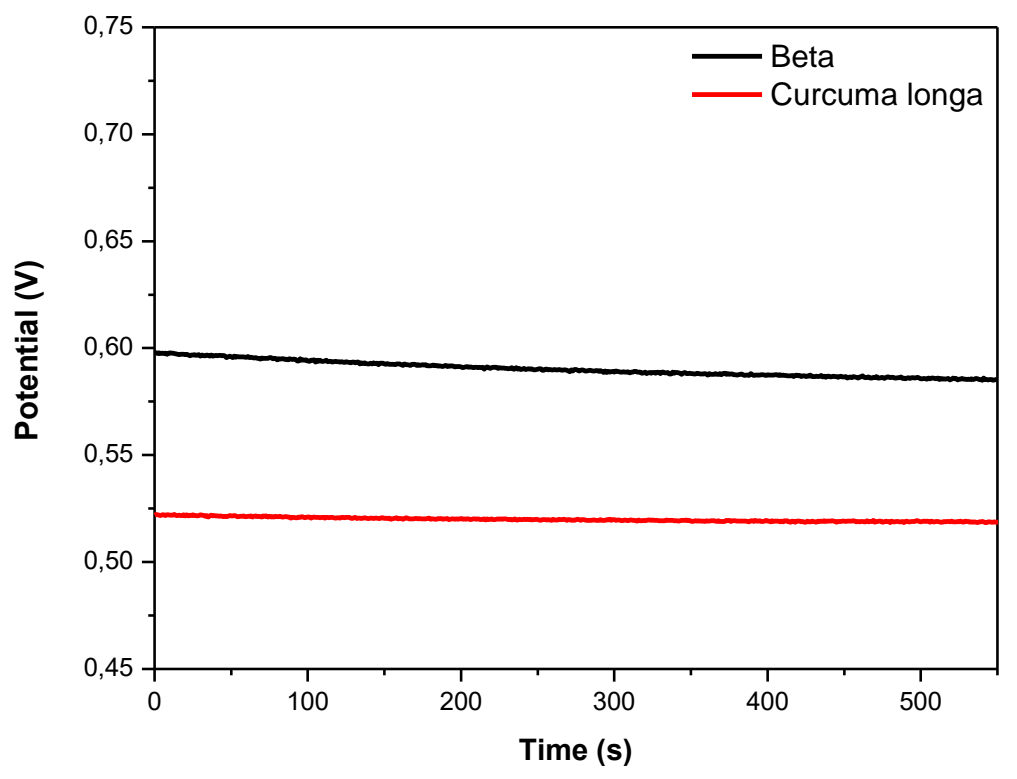

Figure 6. Open circuit potential related to time $(\mathrm{V}$-t) for cells with different dyes tested under $100 \mathrm{~mW} \mathrm{~cm}^{-2}$ illumination

Both systems analyzed by V-t measurements showed a constant potential at a time of about 200 seconds, which is necessary for the temperature of the device to stabilize due to the light incidence used. It is also noticed that the system with the highest potential was extracted from beta, presenting an $\mathrm{Voc}=0.6 \mathrm{~V}$, close to the potential values found for cells using N719 as a sensitizer. ${ }^{20}$

The dye extracted from Curcuma Longa showed a Voc near $0.53 \mathrm{~V}$, suggesting more pronounced recombination effects, but with a higher current density when compared to beta dye. These values are in accordance with literature, because as shown by Calogero and Santiago, high values of photocurrent are obtained in lower potentials. ${ }^{26 .}$ 
Photochronoamperometry curves for both cells, are shown in the Figure 7.

It can be seen in Figure 6 that all $\mathrm{TiO}_{2}$ formed systems were sensitized with the presence of the natural dye, because higher values of photocurrent were obtained when compared to the $\mathrm{TiO}_{2}$ / electrolyte system (DIAS et al.,2018). For the Curcuma Longa dye cell, values close to $\mathrm{j}=0.6 \mathrm{~mA} \mathrm{~cm}^{-2}$ were found, and for the beta cell, $\mathrm{j}=0.4 \mathrm{~mA} \mathrm{~cm}{ }^{-2}$, suggesting that a cell with Curcuma Longa present better efficiency in harvesting light.

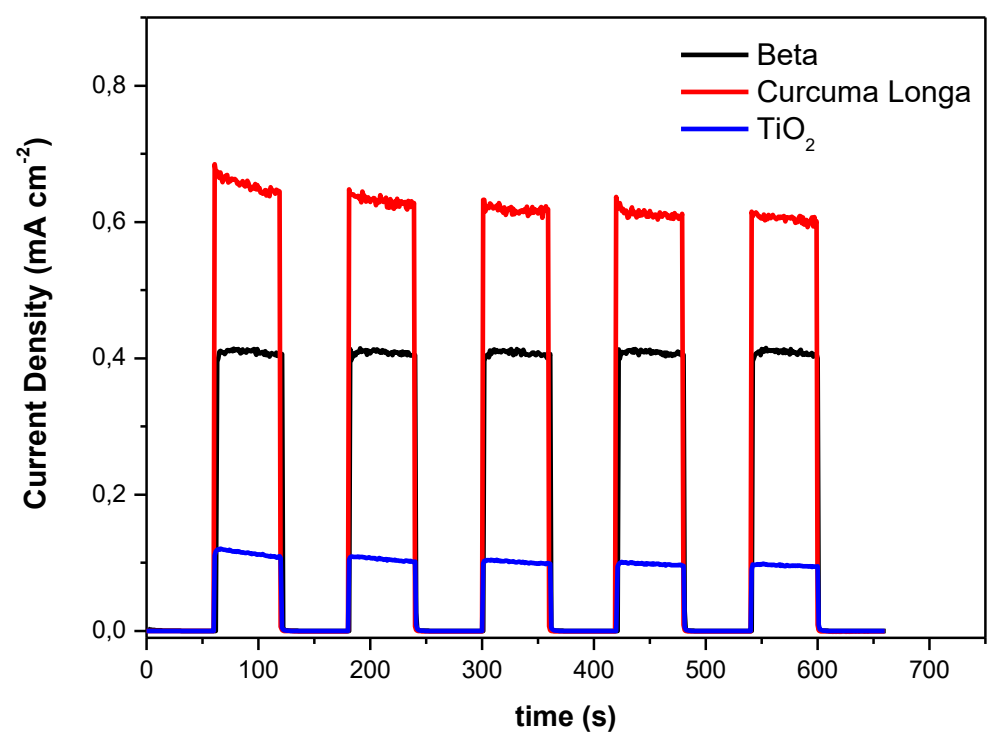

Figure 7. Photocronoamperometric curves for cells studied with the dye from Curcuma Longa and beta extracted at ethanoic solution, tested under illumination of $100 \mathrm{~mW} \mathrm{~cm}^{-2}$

Regarding the loading and unloading capacity, it is verified that all the systems have been successful, because when the light reach the device the current increases instantly, and when the light is interrupted, currents close to $0 \mathrm{~mA} \mathrm{~cm}{ }^{-2}$ are foun. ${ }^{27,28}$ As demonstrated by Tractz et al., it is possible to calculate the photochronoamperometric efficiency (nfca) of the used dye, comparing with a cell without dye, using following equation, which concerns the dye-coating capacity on the surface of the $\mathrm{TiO}_{2}$, providing basic estimates for an adsorptive analysis ${ }^{18,28} \mathrm{In}$ the formula $\mathrm{jTiO}_{2}+$ dye represents the current of the sensitized cell and $\mathrm{jTiO}_{2}$ in absence of sensitization.

$$
\mathrm{\eta}_{f c a}=\frac{j_{T i O 2+d y e^{-}} j_{T i O 2}}{j_{T i O 2}} \quad \text { Equation } 1
$$

It was verified that the system which showed the greatest efficiency in photocurrent production was with dye extracted from Curcuma Longa ( $\mathrm{nfca}=0.83$ ), indicating that in this system there is a greater concentration of organic groups responsible for sunlight, when compared to Beta dye (nfca $=0.75$ ). ${ }^{8,17,18}$ The efficiency is also related to the coating of $\mathrm{TiO}_{2}$ by the dye molecules, so, it is suggested that the curcumin present in the Curcuma Longa is more easily adsorbed on the surface of the semiconductor due to the presence of conjugated double bonds, such as demonstrated by Santiago et al., and also by the presence of auxochrome $\mathrm{OCH}_{3}$ groups. ${ }^{15}$ This factor makes this system more efficient in the ejection of electrons by sunlight when compared to $\mathrm{TiO}_{2}$ systems adsorbed with anthocyanins.

Although curcumin produces cells with better current values, it can be seen in the photocronoamperometric curve that it presents a soft degradation rate, and this result can be related to the conjugated double bonds in the structure of the dye, since the $\mathrm{TiO}_{2}$ in anatase structure is able to react with these regions, degrading the molecule, as demonstrated by Dalponte, 2018. ${ }^{29,16,17}$ The photocurrent decay might be related by the diffusional process because when the photocurrent decays, the device is diffusion-limited by the electrolyte, 
however, the same charge intermediator and assembly, were use in both systems $1 .^{6}$

Figure 8 shows current density curves as a function of potential, which is an extremely useful technique, capable of providing more meaningful parameters for a detailed system analysis ${ }^{9}$.

The curves $\mathrm{j}-\mathrm{V}$ provide all the photovoltaic parameters to calculate the energy conversion efficiency $(\eta)$, using Equation 2, where $\mathrm{j}_{s c}$ corresponds to the short-circuit current (when the potential is zero), $V_{\text {oc }}$ the open circuit potential (when the current is zero), $P_{\text {in }}$ the incident power, and FF the fill factor. ${ }^{7,4,13}$ Table 1 shows the photoelectrochemical parameters extracted from the curves ${ }^{6}$

$\eta(\%)=\frac{\operatorname{Voc} \mathrm{Jsc} F F}{P_{\text {in }}} \cdot 100 \quad$ Equation 2

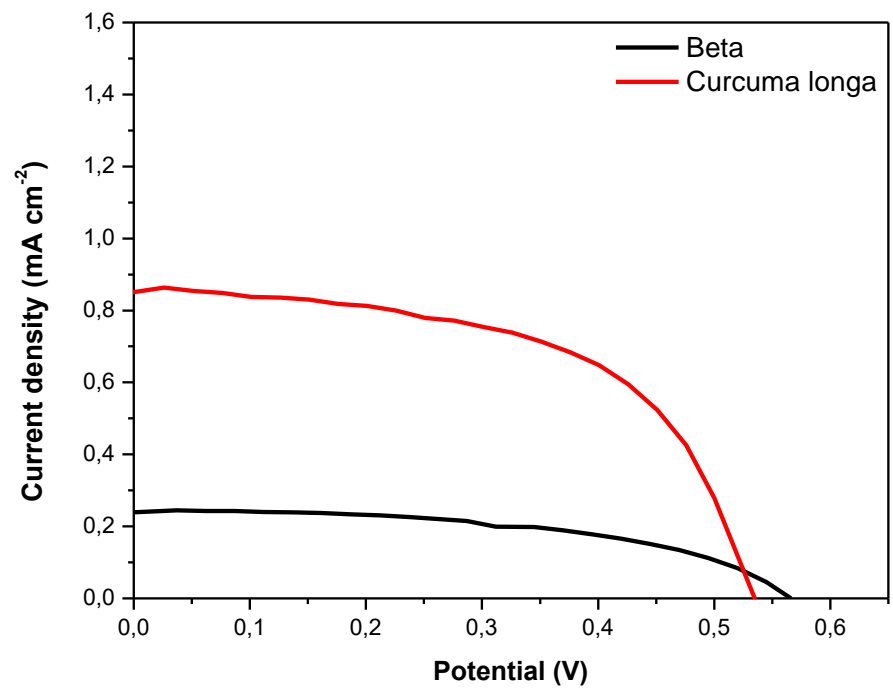

Figura 8. Photocurrent curves as a function of the potential for the systems studied with the different dyes extracted in ethanoic condition at $100 \mathrm{~mW} \mathrm{~cm}^{-2}$ of incident light

Table 1. Photoelectrochemical parameters of the solar cells produced with due extracted of Beta and Curcuma Longa

\begin{tabular}{lllll}
\hline Dye & $\mathrm{V}_{\text {oc }}(\mathbf{V})$ & $\mathrm{J}_{\mathrm{sc}}\left(\mathrm{mA} \mathrm{cm}^{-2}\right)$ & $\mathrm{FF}$ & $\boldsymbol{\eta}(\%)$ \\
\hline Beta & 0.61 & 0.40 & 0.45 & 0.15 \\
Curcuma Longa & 0.53 & 0.86 & 0.56 & 0.26 \\
\hline
\end{tabular}

In the Table 1 the result could be suggested, since as observed in the UV VIS spectra, the dyes analyzed here presented the characteristic of absorbing energy only in the visible light region. ${ }^{8}$

Regarding the fill factor, it can be seen that the highest value found was FF $=0.56$ for the Curcuma Longa dye. This value is a very promising result, seen in studies using dye N719 the fill factor was lower. ${ }^{20}$ This data also implies the energy conversion efficiency of the device.

It can be noticed, the cell that presented the highest energy conversion efficiency was the one produced with the curcumin molecule, present in the Curcuma Longa, providing a system with $\eta=0.26$, close to

the literary values found, and efficiencies greater than $1 \%$ for these devices are rarely found. ${ }^{10,11,13}$ This value is extremely related to the photocurrent density generated by the systems, since small values of $j_{s c}$ generate inefficient cells. ${ }^{8}$ Tractz and co workers related cells with natural dyes with a photoconversion energy efficiency of $0.12 \%, 0.07 \%$ and $0.11 \%$ fot the use of plum, eggplant and grape as natural product, very similar to results found in this paper. ${ }^{18}$

The values of potential and current 
obtained here approximated the results obtained from previous techniques, and the system presenting curcumin molecules present in the Curcuma Longa showed higher photocurrent density and higher efficiency when compared to the system produced with anthocyanin. This value is in accordance with some papers, as related by Kumara, 2017, Tractz, 2018 e Narayan 2012. ${ }^{14,10,28}$

Recent studies demonstrated that different extractive solutions as methanol, and acethonitrile, can be used to prepare the sensitizer and consequently the solar cell, which can generate differentiated photoelectrochemical parameters, but other solutions that could generate more concentrated active species and consequently expand the spectrum and / or to adsorb on the $\mathrm{TiO}_{2}$ surface easily were not analyzed. ${ }^{14}$

In Figure 9 and 10, the Nyquist and Bode diagram, obtained by electrochemical impedance spectroscopy, are observed for systems produced with Curcumin and beta dyes.
For solar cells sensitized by dyes, the first arc in the Nyquist diagram is related to the processes that occur at higher frequencies, that is, highspeed, characteristic of the processes that occur at the Pt / electrolyte interface. The intermediate arc is the most studied in solar cells because it provides information about the $\mathrm{TiO}_{2} /$ dye / electrolyte interface. $^{4}$

It is verified that for the system produced with the beta dye, there is an enormous resistance related to the passage of the electron through the external circuit, until finding the counter electrode, making difficult the formation of the electric current, as evidenced by the curves of $\mathrm{j}-\mathrm{V}$, where a value of $\eta=0.16 \%$ was found to energy conversion. ${ }^{30}$

For the cell produced with the Curcuma Longa dye, the resistance at the anode interface was much lower than the beta dye, consequently generating cells with better current density, due the less resistance to current flow.

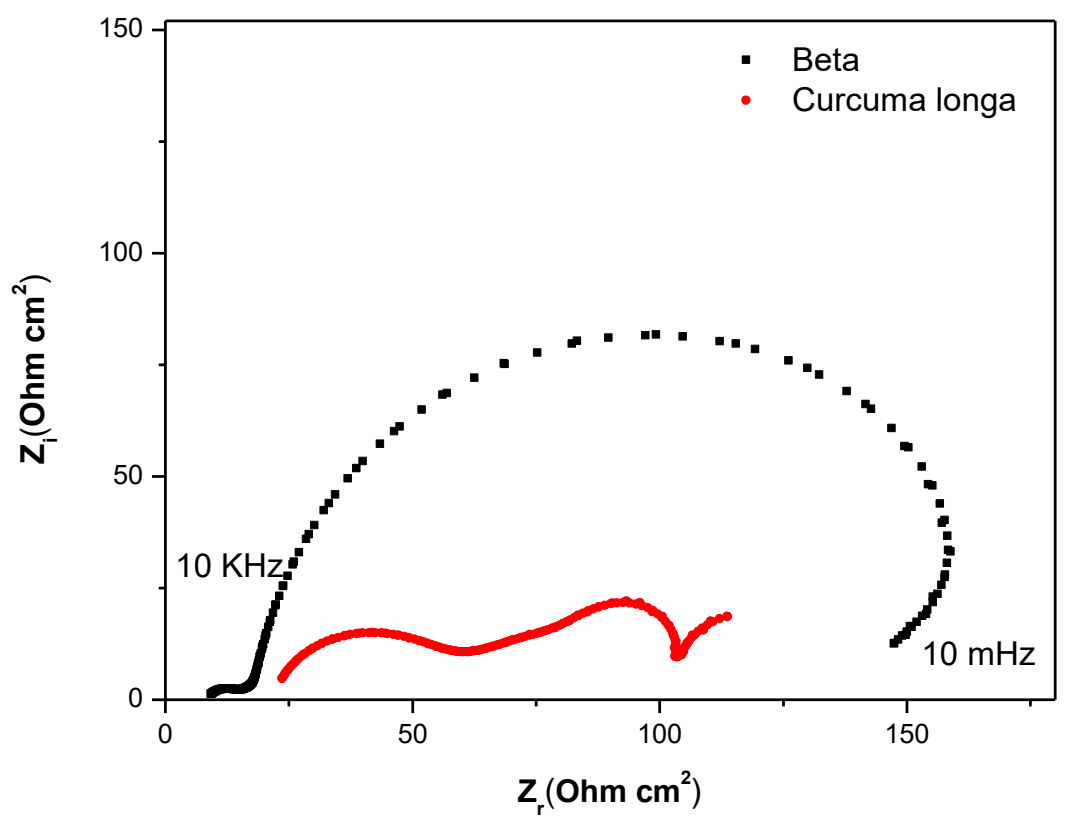

Figure 9. Nyquist diagrams for $\mathrm{TiO}_{2}$ cells with curcumin and anthocyanin dye extracted in ethanoic condition 


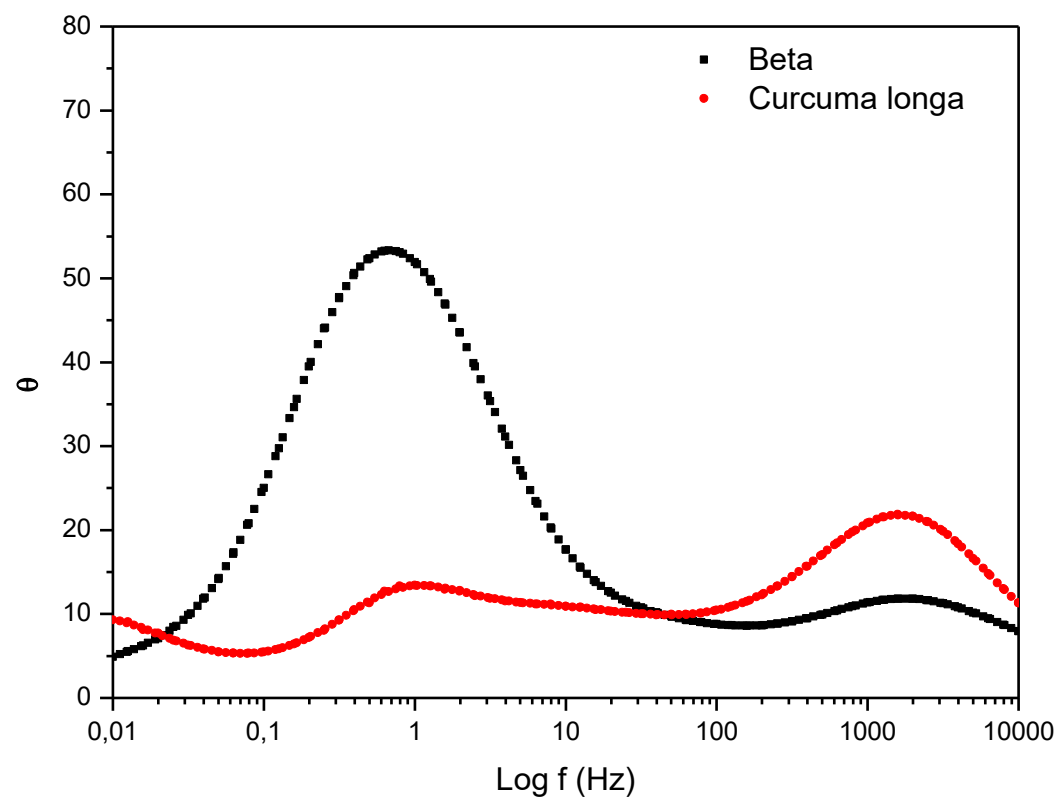

Figure 10. Bode diagrams for $\mathrm{TiO}_{2}$ and dyes cells with curcumin and anthocyanin dye extracted in ethanoic condition

In Figure 9, it is also noticed in lower frequency, the formation of a third capacitive arc to Curcuma Longa dye, related to the diffusion processes of the electrolyte at cell interfaces, which was not visualized for the dye produced from the beta, and also not visualized in studies that use other natural dyes and generate cells with less efficiency in energetic conversion. ${ }^{17,18}$

An extremely important factor also observed for these systems was that both presented the two capacitive arcs with great visualization for the curcumin molecule originating from the Curcuma Longa, as occurs with cells produced with commercial dyes. ${ }^{30}$ In the literature, we find impedance studies, where the resistance of the anodic interface is extremely greater than the resistances of the cathodic interface, where only one capacitive arc appears in the Nyquist diagram. ${ }^{30}$

The behavior obtained here for the analyzed systems approaches the reference cells produced and studied in the world market, showing that it is possible to make use of sustainable and low-cost resources for the production of clean energy.

\section{Conclusions}

Both dye presented sunlight absorption in visible region and with adsorption onto $\mathrm{TiO}_{2}$ surface. However the dyes used, did not show the capacity to absorb in infrared region.

All the devices produced were photosensitive, as proven in the photocronoamperometry curves, with a good charging / discharging time, presenting a mean current density equivalent to $0.6 \mathrm{~mA} \mathrm{~cm}^{-2}$ and $0.4 \mathrm{~mA} \mathrm{~cm}^{-2}$ respectively for with curcumin and anthocyanin dye.

Among the produced systems, the one with the highest photoelectrochemical parameters is the one produced with a curcumin molecule from Curcuma Longa with energy utilization $\eta$ $=0.260 \%$, having as photovoltaic parameters an $\mathrm{Voc}=0.535, \mathrm{FF}=0.560$ and $\mathrm{a} \mathrm{jsc}=0.860 \mathrm{~mA}$ $\mathrm{cm}^{-2}$ with better dye adsorption in $\mathrm{TiO}_{2}$ surface.

Curcumin dye may generate systems with better interface reactions, since it were noted in EIS measurements, with three capacitive arcs, generating a cell with low resistance of charge transportation, when compared to cell sensitized with anthocyanin. 


\section{Acknowledgements}

The authors are grateful to SETI/UGF, CNPq, CAPES, UNICENTRO and the trainees of the UNICENTRO water laboratory, for the measurements in the UV-VIS spectrophotometer.

\section{References}

${ }^{1}$ Al-Alwani, M. A. M.; Mohamad, A. B.; Ludin, N. A.; Kadhun, A. A.; Sopian, K. Dye sensitized solar cells: Development, structure, operation principles, electron kinects, characterization, synthesis materials and natural photosensitizers. Renewable and sustainable Energy Reviews 2016, 65, 1. [CrossRef]

${ }^{2}$ Lima, R. M. C.; Medeiro, R. A.; Fonseca, M. G.; Dere, N. G.; Shinde, O.; Schneller, E.; Pinheiro, W. A.; Ferreira, I. C.; Cruz, R. L. Caracterização de células solares de filmes finos de CIGS. Revista Matéria 2007, 22, 3. [CrossRef]

${ }^{3}$ Gratzel, M. Photoelectrochemical Cells. Letters to Nature 2001, 414, 15. [CrossRef]

${ }^{4}$ Guimaraes, R. R; Parussulo, A. L. A; Matias, T. A; Toma, H. E; Araki, K. Electrostatic blocking barrier as an effective strategy to inhibit electron recombination in DSSCs. Eletrochimica Acta 2008, 255, 20. [CrossRef]

${ }^{5}$ O'Regan, Brian; GRATZEL, M. A low-cost, high efficiency solar cell based on dye - sensitized solar cell. Letters to Nature 1991, 353, 6346. [CrossRef]

${ }^{6}$ Longo, C.; Paoli, M., Dye sensitized solar cells: A successful combination of materials. Journal of the Brazilian Chemical Society 2003, 14, 889. [CrossRef]

${ }^{7}$ Barea, E. M.; Zafer, C.; Gultekin, B.; Aydin, B.; Koyuneu, S.; Ecli, S.; Santiago, F. F.; Bisquert, J., Quantification of the effects of recombination reaction and injection in the performance od dyesensitized solar cells based on $\mathrm{N}$-substituted carbazole dyes. Journal of physical chemistry 2010, 114, 19840. [CrossRef]

${ }^{8}$ Hangfeldt, A.; Boschloo, G.; Sun, L.; Kloo, L.; Pettersson, H. Dye Sensitized solar cells,
Chemical Review 2010, 110,11. [CrossRef]

${ }^{9}$ Kumara, N.T.R.N.; Ekanayake, P.; Lim, A.; Iskandar, M.; Ming, L. C., Study of the enhancement of cell performance of dye sensitized solar cells sensitized with Naphelium lappaceum, Journal of solar energy engineering 2013, 1335, 1. [CrossRef]

${ }^{10}$ Narayan, M. Review: Dye sensitized solar cells based on natural photosensitizers. Renewable and sustainable energy reviews 2012, 16, 12. [CrossRef]

${ }^{11}$ Richhrariya, G.; Kumar, A., Fabrication and characterization of mixed dye: Natural and synthetic organic dye. Optical Materials 2018, 19, 296 [CrossRef]

${ }^{12}$ Shalini, S.; Balasundaraprabhu, R.; Kumar, T.S.; Sivakumaran, T.S.; Kannan, M.D., Synergistic effect of sodium and yeast in improving the efficiency of DSSC sensitized with extract from peals of Kigelia Africana.Optical Materials, 2018, 79, 210. [CrossRef]

${ }^{13}$ Wongcharee, K; Meeyoo, V; Chavadej, S. Dye-sensitized solar cell using natural dyes extracted from rosella and blue pea flowers. Solar Energy Materials and solar cells 2007, 91, 7. [CrossRef]

${ }^{14}$ Kumara, N. T. R. N; Lim, A; Lim, C. M; Petra, M. I; Ekanayake, $\mathrm{P}$. Recent progress and utilization of natural pigments in dye sensitized solar cells: $A$ review. Renewable and sustainable energy reviews 2017, 78, 1. [CrossRef]

${ }^{15}$ Santiago, S. V.; Silva, G. P. M.; Ricardo, D. D.; Lima, M. E. F., Curcumina. O pó dourado do açafrão da terra: instrospecções sobre química e atividades biológicas, Química Nova 2015, 4, 538. [CrossRef]

${ }^{16}$ Dias, B. V.; Tractz, G. T.; Viomar, A.; Maia, G. A. R.; da Cunha, M.; Rodrigues, P. R. P., Photoelectrochemical behavior of the cell $\mathrm{FTO} / \mathrm{TiO}_{2} / \mathrm{CeO}_{2} / \mathrm{N} 719$ obtained from the pechinni and precipitation of cerium oxide methods. Journal of electronic materials 2018, 47,5556 . [CrossRef]

${ }^{17}$ Tractz, G. T.; Maia, G. A. R.; Dias, B. V.; Banczeck, E. P.; Molinares, M. A.; Cunha, M. T.; RodrigueS, P. R.P., Influence of deposition methodology and heating treatment on dye 
sensitized solar cells with natural extract. Orbital: The electronic Journal of Chemistry 2018, 10, 204. [CrossRef]

${ }^{18}$ Tractz, G. T.; Maia, G. A. R.; Dias, B. V.; Banczeck, E.; Cunha, M. T.; Rodrigues, P. R. P., Estudo de células solares híbridas de $\mathrm{TiO}_{2}$ com corantes naturais. Revista Virtual de Química 2018, 10, 1074. [CrossRef]

${ }^{19}$ Lee,C. R.; Kim, H. S.; Jang, I. H.; Im, J. H.; Park, N. G., Pseudo First order adsorption kinects of N719 dye on $\mathrm{TiO}_{2}$ surface. ACS applied materials and interfaces 2011, 3, 1953. [CrossRef]

${ }^{20}$ Viomar, A.; Maia, G. A. R.; Scremin, F. R.; Khalil, M. N.; Cunha, M. T.; Antunes, A. C.; Rodrigues, P. R. P. Influência do método de obtenção de partículas de Nb205 empregadas em células solares sensibilizadas por corante compostas de TiO2/Nb2O5. Revista Virtual de Química 2016, 8, 3. [CrossRef]

${ }^{21}$ Lopes, T. J.; Xavier, M. F.; Quadri, M. G. N. Antocianinas: uma breve revisão das características estruturais e da estabilidade. Revista Brasileira de Agrociência 2007, 13, 3. [CrossRef]

22 Laczkowski, M. S.; Laczkowskl, I. M.; VIII Encontro de Produção científica e tecnologica, Campo Mourão, Brasil, 2013. [CrossRef]

${ }^{23}$ Patrocínio, A. O. T.; Ilha, N. Y. M. Em busca da sustentabilidade: Células solares sensibilizadas por extratos natuais. Química Nova 2010, 33, 3. [CrossRef]

24 Boschloo, G.; Hagfeldt, A. Activation energy of electron transport in dye sensitized solar cells. Journal of Physical Chemistry 2005, 109,
12093. [CrossRef]

${ }^{25}$ Duffy, N. W.; Peter, L. M.; Rajapakse, R. M. G.; Wijayantha, K. G. U. Investigation of the kinects of the back reaction of electrons with tri-iodide in dye sensitized nanocrystalline photovoltaic cells, Journal of the Physical Chemistry B 2000, 140, 8916. [CrossRef]

${ }^{26}$ Calogero, G.; Di Marco, G. Red sicilian orange and purple eggplant fruits as natural sensitizers for dye-sensitized solar cells. Solar energy materials and solar cells 2010, 92, 11. [CrossRef]

${ }^{27}$ Maia, G. A. R.; Larsson, L. F. G.; Viomar, A.; Maia, E. C. R.; Santana, H.; Rodrigues, P. R. P. Aperfeiçoamento da produção de partículas de óxido de zinco para aplicação em células solares. Cerâmica 2016, 62, 361. [CrossRef]

28 Tractz, G. T.; Maia, G. A. R.; Dias, B.V; Ignachewski,F.; Rodrigues, P. R. P.; Avaliação da adsorção e estudo eletroquímico de células solares produzidas com $\mathrm{TiO}_{2}$ e corante extraído do hibiscos. Química Nova 2018, 41, 512. [CrossRef]

${ }^{29}$ Dalponte, I.; Tese de Doutorado, Universidade Federal do Parana, Brasil, 2018. [Link]

${ }^{30}$ Ghan, W.; Kang, H.; Sheikh, T.; Yadav, S.; Gil, T. C.; Nesbitt, F.; Uddin, J. Fabrication, optimization and characterization of natural dye sensitized solar cell. Scientific reports 2017, 7, 1. [CrossRef]

${ }^{31}$ Gratzel, M. Dye-sensitized solar cells. Journal of Photochemistry and Photobiology C: Photochemistry Reviews 2003, 4, 2. [CrossRef] 